\title{
Innocent IV, John XXII, and the Michaelists on Corporate Poverty
}

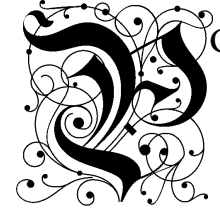

OOPE JOHN XXII (r. 1316-1334) and the Franciscan dissidents centred around Michael of Cesena (c. 1270-1342) covered a lot of ground in the course of their writings on the nature and Cxtent of evangelical poverty. But if much of the terrain had already been explored in the preceding eighty or so years, both sides still managed to break new paths and chart old ones with greater precision. One issue that came under close scrutiny in the controversy of the 1320 s had to do with the corporate poverty of the Franciscan Order. As it was, in many ways, the Franciscans' corporate poverty that distinguished them from other mendicant orders, ${ }^{1}$ it is no surprise that this issue was closely scrutinized by the polemicists. It is, however, a question that has received less attention in the hands of modern scholars.

The origins of the doctrine of the corporate poverty of the Franciscans is well known. Two passages from St Francis show (at least) the kernel of this ideal. The first comes from his Rule, where he wrote that 'the brothers are to appropriate nothing: neither a house, nor a place-in short, nothing;

* This paper is unrelated to those presented at the 2006 ACMRS Conference, 'Poverty and Prosperity, the Rich and the Poor in the Middle Ages and Renaissance' (16-18 February 2006) and the 'Cornell Conference on Medieval Poverty' (28-30 March 2008). I would, however, like to thank the participants of both for their helpful comments. All translations are my own.

1 See, e.g., Michael of Cesena's interpretation of Regula bullata 6.1-6 (in Esser 1978, 231-32), in the Appellatio monacensis (= App. mon.; ed. in Gál and Flood 1996, henceforth G\&F, 677-78. Note that Wittneben 2003, esp. pp. 353-79, has provided a detailed case for designating Bonagratia the principal author of the two Pisan appeals (Appellatio maior [= App. mai.] and Appellatio minor [= App. min.]); I call them Michael's only in the sense that they were published in his name. 
rather they are to go out confidently for alms as strangers and guests, following the Lord in poverty and humility'2 And in his Testament, St Francis exhorted the brothers 'to avoid completely the receiving of churches, poor dwellings, or anything built for them unless they be appropriate to holy poverty, which they have promised in the Rule-always staying there as pilgrims and guests' 3 In 1230, only a few years after St Francis' death, Gregory IX (1227-1241) declared that the Testament was not a binding document, 4 but he followed in its steps somewhat by decreeing that the Franciscans must have ownership neither in common nor individually, but that 'the Order may have the use of equipment and books, and of the movable property it is licit to have.' Fifteen years later in Ordinem vestrum, his own bull on this topic, Innocent IV (1243-1254) said much the same thing. ${ }^{5}$ In this way, though perhaps not in so straightforward a manner, the doctrine of Franciscan corporate poverty found papal approbation.

The story of how the attacks upon and defence of the theory of Franciscan poverty became increasingly sophisticated in the thirteenth and early fourteenth century is one often told. ${ }^{6}$ At the moment we need only bear in mind there existed a venerable tradition of defining Franciscan poverty in terms of a lack of individual and communal ownership. Corporate poverty, however, could seem problematic when one thought about it. If the friars did not own the things they used, who did?

As Innocent explained in Ordinem vestrum, his intention was to solve problems like these; Gregory, apparently, had only done half the job (exposuerit, et declaraverit semiplene). ${ }^{7}$ Innocent began the relevant section

$2 \quad$ Regula bullata 6.1-2 (Esser 1978, 231).

3 Testamentum 24 (Esser 1978, 312).

4 The basis for Gregory's judgement had its source in two legal common-places; see Quo elongati (Grundmann 1961, 21, 11. 35-38): ' [...] ad mandatum illud vos dicimus non teneri, quod sine consensu fratrum et maxime ministrorum, quos universos tangebat, obligare nequivit nec successorem suum quomodolibet obligavit, cum non habeat imperium par in parem' Grundmann discussed the second of the these common maxims in his the course of his introductory essay ( 4 and n. 1); for the first maxim, see, e.g., Y. M.-J. Congar 1958, and Post 1946.

5 Grundmann 1961, 22. Ordinem vestrum can be found in Sbaralea and Eubel 1983 (= BF) 1:400a-O2b, n. 114. For the comparison of Ordinem vestrum to Regula bullata and Quo elongati, one should consult above all Pásztor 1986, 104-12. See Elizondo 1962 , for lengthy discussion of both Quo elongati and Ordinem vestrum.

6 The bibliography is huge. Important recent overviews include: Burr 2001; Lambert 1998; Lambertini 2000; and Mäkinen 2001.

7 BF, 1:400a, n. 114 . 
of the bull with the same reference to the Rule Gregory had made, and a paraphrase of what Gregory had to say about the matter, who had included a statement to the effect that, concerning the things which the friars could use, the 'lordship of the places and houses [is] reserved to those to whom it is known to pertain.' Nor, Gregory had continued, ought the movable goods be sold, exchanged, or alienated in any other way without the sanction of Cardinal in charge of the Order. ${ }^{8}$ Though he has often been criticized for missing the point when it comes to Franciscan poverty, ${ }^{9}$ on this point at least, Innocent's 'fuller clarification' seems common-sense enough. As he explained, the friars must not exchange these goods, because the ius, proprietas, et dominium belong directly to the Church except where the donors wish to retain lordship and ownership. ${ }^{10}$ This was a development of Gregory's position, for while Gregory was willing to assume by 'to whom it is known to pertain,' everyone would understand the same thing, Innocent felt the need to say explicitly who the owner was for any good the Franciscans used: either the donor who wanted to keep ownership and lordship, or the Church itself-not, that is, the Franciscans. ${ }^{11}$

It is tempting to speculate about the reasons for Innocent's addition, both here and in the other aspects of Ordinem that were not as well received by the Order. ${ }^{12}$ But in the case of accepting the 'right and ownership,' the answer is probably simple enough: 'In this way [Innocent]

8 Quo elongati, 22-3, 11. 85-91.

9 Cf. Brooke 1959, 250-51, Moorman 1998, 117, and Pásztor 1986, 108. For analysis of the contents, see Damiata 1978-1979, 1:112-25; Elizondo 1962, 369-75, and Lambert 1998, 101-07. From a related perspective, see Mueller 2006, 96-97.

$10 \quad$ BF 1:401b, n. 114.

11 Moorman 1998, 120. Cf. Lambert 1998, 106-o7: Quo elongati 'had set it down that the friars were obliged by their Rule to make a total renunciation, as an order, of all forms of dominion or property rights. [Ordinem vestrum] had put forward a theoretical system, a legal fiction indeed, which would enable the order to observe this total renunciation.

12 See, e.g., the Diffinitiones narbonensis, n. 13, ed. in Delorme 1910, 503: 'Declaratio domini Innocentii maneat suspensa, sicut fuit in capitulo Methensi [1254]; et inhibemus districte, ne aliquis utatur ea in hiis, in quibus declarationi domini Gregorii [i.e., Quo elongati] contradicit' However, we never get the sense that the papal retentio dominii was one of these points: subsequent papal declarations repeated the claim-e.g., Clement IV, Cum dilecti (25 July 1265), BF 3:24b, n. 26; Gregory X, Voluntariae (5 November 1274), BF 3:222b, n. 58; Martin IV Exultantes (18 January 1283), BF 3:501 b, n. 40-and the Michaelists, at least, were keen to 
put an end to a nagging question with which critics of the Order had easily disturbed the brothers. Who owned the bucket with which the brother carried out the kitchen swill? The pope did.' ${ }^{13}$ The rationale and effect of Innocent's move is easy to understand, but it could also be described in a more technical sense: the pope was, in fact, forestalling the possible objection that one became the owner merely by using an unowned thing, a res nullius in Roman law.

The basic problem was that a thing was generally considered abandoned if the former owner had no intention to retain ownership of the thing in question. ${ }^{14}$ Although physical possession of a thing available for acquisition was only one of the two necessary criteria for establishing ownership - the other being an intention to acquire ownership ${ }^{15}$ - it was the prior consideration. Now, however, even if it were argued that a friar wanted to claim ownership of the slop bucket, he had no legal claim to it. Innocent's retentio dominii thus served as a clear legal buffer against one avenue of attack against the theory of Franciscan poverty.

\section{JOHN XXII ON 'ORDO HABEAT USUM'}

There were, however, many others. Pope John XXII used most of them; and in Ad conditorem canonum, he even reversed Innocent's policy of papal overlordship of the (otherwise unowned) things the Franciscans used. ${ }^{16}$ Of course, since his opponents believed that John proved himself to be a heretic ipso facto, ${ }^{17}$ and that he only re-affirmed this fact through the publication of Cum inter nonnullos (1323), they were more worried that

cite them; see App. mon., 846-47, and Ockham's Opus nonaginta dierum (=OND) 71.159-177, in Offler et al. 1956-1997 (= OP) 2:597-98.

13 Flood, 'Franciscan Poverty', in G\&F 14.

14 Cf. Inst. 2.1.47. Inst. 2.1.48 highlights that the intention to abandon a thing must also be present. All references to Roman law are taken from Krueger et al. 1966; Cod., Dig., and Inst. refer to Justinian's Code, Digest, and Institutes respectively.

15 See, e.g., Dig. 41.2.3.1: 'Et apiscimur possessionem corpore et animo, neque per se animo aut per se corpore' Further discussion in Berger 1953, 637 (sv. 'possessio'), and Miller 1998, 53-55, 58-6o. Cf. App. mon., 843-44.

16 See $A d$ cond. ${ }^{1}$, ed. in G\&F, 87, and the longer version, Ad cond. ${ }^{2}$ 239-286, in Tarrant 1983, 249-53. The pope published this bull twice, first in December 1322, then again about a month later (though with the same date).

17 See, e.g., the Appellatio Ludovici de Sachsenhausen, in G\&F, 145. 
people might actually believe that the pope's arguments were valid, not about what kind of binding legal effect his bulls had.

Considering the fact that the pope had already stated his opinions on the orthodoxy of apostolic poverty, and renounced papal overlordship of the friars' things, one might wonder why he would bother to publish yet another bull on the matter. I suspect it is a sign that, like his scholastic opponents, the lure of an academic controversy proved to strong to ignore. ${ }^{18}$ Whatever the motivation, though, in 1324 John published Quia quorundam mentes, which, among other arguments, maintained that Franciscans could not actually practice corporate poverty, at least in the way they conceived of it. ${ }^{19}$ After quoting the portions of Quo elongati and Ordinem vestrum where it is said that the 'Order may have [the] use' (ordo habeat usum), John explained that this had to be a 'use of right.' It could not be a 'use of fact,' he said, because facta require a persona vera, and an ordo is considered to be an imaginary and represented person. Therefore, he concluded, only things of right, not of fact, are appropriate to an Order. ${ }^{20}$ As usual, John was making a legal point that he felt no need to explain. Orders are legal entities, and as such, they do not perform actions in the sense that a real person does. That is, even if the papacy owned the bucket that was used to carry things about, the Order did not factually use the bucket: rather, a friar did. Hence the pope's contention that it is clearly shown that, of those things which it was licit for those selfsame brothers to have, a use of right pertains to the same Order'21

It is as easy to over-simplify the pope's argument as it is to misunderstand it. James Heft once wrote that John's argument was merely 'a syllogism based on the civil law understanding of his day,' which is true

18 We would do well to remember that interest in the Michaelist cause is hard to find beyond an academic milieu. It was fading fast in the year Michael of Cesena published his two Appeals, and had vanished barely a decade later. See Robson 2006, 140.

19 Miethke $1969,502-16$, has discussed the problem at some length, particularly as it applies to the Michaelist-John controversy. See also Kriechbaum 1996, 54-76.

20 Quia quorundam mentes (Tarrant 1983, 267), 11. 117-122. I use 'Order' throughout to emphasize the abstract nature of the Franciscan Order to which the disputants referred.

21 Quia quorundam 104-105 (Tarrant 1983, 266); cf. Quia quorundam 209-216 (Tarrant 1983, 274-75). Brunner 2006, 233-34, who kindly sent me a copy of her dissertation to read, has offered the intriguing suggestion that John may also have been influenced by his experiences at the law school of Orléans on this whole topic. 
enough, but it hardly explains what is at stake. ${ }^{22}$ After all, it was William of Ockham, not John XXII, who is known for his 'logical individualism,'23 yet obviously if Ockham were to defend the corporate poverty of his Order, which included renouncing all positive law-derived rights, it would have to be the nominalist who defended the factual use of an Order. ${ }^{24}$

The pope had a lot more to say about the nature of property, rights, and the requirements for just/licit use, ${ }^{25}$ but what I would like to do in the remainder of this paper is look at how the leading Michaelists, who collectively spanned the disciplines of theology and law, responded to John's tacit legal argument. Before we turn to the Michaelists, though, it is worth considering what Innocent would have thought of John's argument, for he was, after all, a leading exponent of the idea that a corporation could be considered a persona ficta et repraesentata. ${ }^{26}$

\section{INNOCENT IV'S 'FICTION' THEORY}

A preliminary remark is in order regarding the so-called fiction theory. Fascinating as they are, we shall not get mired in the old-fashioned debates between the 'realist' and 'fiction' theory of corporations. ${ }^{27}$ However, as

22 Heft 1986, 73. It should be noted, however, that the argument found a home among the canonists rather before the civilians.

23 McGrade 1980, 152, made this very point; he also used the term 'logical individualism' passim.

24 The problem is all the more poignant for the fact that a recent study on Ockham explains that 'Ockham's "logical individualism" would reject any kind of corporation theory. No such entity as a "corporation," set apart from individuals, can exist' Or that 'Ockham's logical individualism' would refuse to accept Marsilius' 'idea of collective representation' See Shogimen 2007, 191, 215-16; cf. Canning 2005, 476.

25 I have discussed this with respect to John XXII and William of Ockham in a paper entitled 'William of Ockham on the Right to (Ab-)Use Goods', in Robinson 2009.

26 This paper thus focuses on the arguments for and against an Order's use; one should bear in mind that, regarding corporate poverty, as much or more could be said about theories about corporate lordship or ownership. Also, I use 'corporation' throughout in the generic sense, much like Johannes Andreae, Novella ad VI 5.11.5, nn. 8-9: 'Nomina universitas, communitas, collegium, corpus, societas sunt quasi idem significantia'; quoted in Canning 1980, 17. As we shall see, the Michaelists often used these kinds of terms when talking about the apostles as a group, or generic (religious) communities.

27 See the classic account in Maitland's introduction to his translation of Gierke 1938, xiv-xliii. Tierney 1988, 58-59, has suggested the limited usefulness of this debate; see further Canning 1980, 17-19, and Tierney 1998, 91-97. 
there is much truth to the claim that Innocent was a proponent of $a$ fiction theory, if not 'the Fiction Theory,' ${ }^{28}$ I shall continue to employ this terminology.

The fiction theory, in the medieval sense, is described as such because the corporation-the universitas to use most generic term-as such is merely a fiction of the law. ${ }^{29}$ The source for the claim that Innocent was an adherent of this view comes from a comment on a decretal that is not actually a part of the Liber extra. ${ }^{30}$ For our purposes the content of the decretal is more important than its status in the official version of Gregory's Decretales, viz, a decision regarding the lawsuit between two monasteries over a question of corporate poverty. One issue involved the swearing of oaths. Could an abbot or prior swear an oath in his own name and on the souls of those religious communities (nomine suo et in animas conventuum eorundem)? Innocent first stressed that the one swearing the oath had to respond 'according to the will of the majority.' ${ }^{1}$ He then went on to write that it makes sense for the animae conventuum to swear through one person if they wish 'since, in a matter concerning the corporation, a college is contrived of as one person' (cum collegium in causa uniuersitatis fingatur una persona). ${ }^{32}$ Innocent also made a similar point with specific reference to a universitas religiosorum. Religious corporations can also swear through someone else; this is, in fact, the normal way of doing things: a procurator introduces the lawsuit and another person (principalis persona) swears and responds in the case. 33 These passages illustrate well at least part of John XXII's claim: certainly an Order is, according to Innocent, a 'represented' person insofar as it is something

28 Rodriguez 1962, 312 (his emphasis); my understanding of Innocent's position owes much to this incisive article. One should also consult Ullmann 1948; for general surveys, see Pennington 2005, 444-49, and Canning 2005.

29 On medieval corporative terminology in general, see Michaud-Quantin 1970; in the commentary tradition to Aristotle's Politics, the preferred term was civitas or communitas, but this is a more specialized usage deriving ultimately from the early Moerbeke translation. See Quillet 1971, 188-89.

30 In Innocent's commentary, there are two extra decretals added to X 2.20 (De testibus et attestationibus). For the details of this confusion, see Rodriguez 1962, 309-10.

31 Innocent IV, Commentaria ad X 2.20.57, n. 4 (fol. 27ova). References are to the facsimile reprint of the Frankfurt edition of 1570.

32 Innocent IV, Commentaria ad X 2.20.57, n. 5 (fol. 27ovb).

33 Innocent IV, Commentaria ad X 2.1.14 (fol. 194rb). 
that can be represented by one person. 34 But to determine whether he thought it was also an 'imaginary' person requires further attention.

In Innocent's view, though it may be thought of as one person in certain circumstances, a corporation is not really a person. It cannot, for example, be excommunicated, 'for a corporation, like a chapter, a people, a nation, and other things of this sort, are names of the law, not of persons.' 35 He went on to explain that excommunicating a corporation would entail condemning the innocent along with the guilty, which is hardly an equitable thing to do. ${ }^{36}$ It seems, then, that while a corporation can be represented legally, even as a person in certain capacities, he also believed, with Accursius, that 'a corporation is nothing but the individual men who are [there].' 37 Or, to use Innocent's words, 'a chapter, which is a term for the intellect (nomen intellectuale) and incorporeal thing, can do nothing except through its members.' ${ }^{8}$ The same seems to be true in legal cases: people, not corporations are liable in court. According to Innocent, 'a corporation cannot be prosecuted or punished, only the delinquent persons; moreover, they can be sued in a civil case (ciuiliter), and fined for the delict of the rectors.' 39

What, then, should we say of Innocent's views about the nature of a corporation? It is certainly true that Innocent was more interested in dis-

34 Cf. App. mon., 750, where Michael described Peter as swearing on behalf of the other apostles. See also App. mon., 773 .

35 Innocent IV, Commentaria ad X 5.39.52(53), n. 1 (fol. 557(559)rb). Cf. Commentaria ad X 1.38.15, n. 4 (fol. 172va-b). See Miethke 1969, 503-04.

36 Innocent IV, Commentaria ad X 5.39.52(53), n. 2 (fol. 557(559)rb-557(559)va). See Rodriguez 1962, 299-301, for an elaboration of this point.

37 Glos. ord. ad Dig. 3.4.7.1 s.v. 'non debetur' For the Glossa ordinaria to the Corpus iuris civilis, I have used Fehi 1965. The version of the gloss cited in Canning 1980, 12-13, includes 'ibi' See Michaud-Quantin 1970, 206-07 for discussion.

38 Innocent IV, Commentaria ad X 5.39.64, n. 3 (fol. $564 \mathrm{rb}$ ). This is part of a longer section that begins by noting that when a chapter is compelled to do something, we understand that to mean that the members of the chapter are compelled.

39 Innocent IV, Commentaria ad X 5.3.30 n. 1 (fol. 5oova-b). Innocent's commentary shows a key difference here. My text reads ciuiliter autem conueniri et pecuniariter puniri possunt ex delicto rectrorum, while Rodriguez' $(1962,304)$ reads potest, which justifies his claim that a corporation 'can be cited as a defendant in a civil suit in tort.' Both what follows and Innocent's referece to X 5.3.19 seem to suggest possunt is the better reading, but without further work on the textual tradition, we cannot be certain how much 'personality' Innocent was prepared to give to corporations on this point. 
cussing corporations in relation to the practical problems of ecclesiastical administration than in elaborating an abstract theory of their metaphysical status,$^{40}$ yet this is not to deny that the rudiments of such a theory might lie scattered throughout his writings. As it turns out, Innocent described two types of corporate entities. In a comment on the phrase 'unum corpus' in a decretal about the establishment of a college, Innocent described two types of colleges. There are collegia personalia, which are comprised of of professions, conducting affairs, religious orders; these are voluntary rather than necessary corporations. Necessary and natural colleges are those that form by reason of origin or residence, such as colleges of a city, town, or Church. But, Innocent clarified, this is not a distinction held in iure, it is only said by analogy to real and personal servitudes. ${ }^{41}$ This analogy is suggestive, but ultimately of little use. Servitudes in Roman law were classified as iura in re aliena, rights over another's property, which were vested in the beneficiary as a right attached to the immovable property..$^{42}$ Personal servitudes, unlike praedial servitudes, ${ }^{43}$ could not be alienated to another, and tended to be extinguished upon the death of the beneficiary. Usufruct, (bare) use, and habitation were all classified as personal servitudes in Roman law. In Justinian's Institutes, 'bare use' is said to be established and extinguished in the same way usufruct is; there is, however 'less right' in use than usufruct; one who has the use of a house, for example, is considered to only have a use of right, which is non-transferable. ${ }^{4}$

A proper understanding of servitudes, then, surely helps us understand what John meant about the Order's use being a use of right, and that this was tantamount to a right of using, ${ }^{45}$ but it does not really help us understand why a collegium religionum is personale. Presumably the

40 See Tierney $1998,94-97$, for some apposite cautionary remarks on this question.

41 Innocent IV, Commentaria ad 5.31.14, nn. 4, 5 (fol. 526va).

42 For details, see Berger 1953, 702-03 (s.v. 'servitus'), and the references there; also Miller 1998, 66-75.

43 We should assume that Innocent was referring to praedial servitudes when he wrote of 'real' servitudes. A praedial servitude—servitutes rerum, iura praediorum-tended to be for the economic exploitation of some immovable property.

44 Inst. 2.5 pr.-2. Cf. Dig. 7.8.1 and 7.8.8.

45 John's explicitly defined usus as a personal servitude at Ad cond. ${ }^{2}{ }_{108-111}$ (Tarrant 1983,238 ), which he repeated in Quia vir, in G\&F 555-56. Ad cond. ${ }^{1}$ lacked a specific definition, but, significantly, John did use the term nudus usus; see Ad cond. ${ }^{1}, 85-86$. This is another place where John felt it was unnecessary to point out 
point is that a religious college-an ordo-is 'personal' in that it inheres in the people who comprise it, rather than the 'real' colleges (cities, towns, churches), which would seem to inhere in the place itself. But this only brings us back to Azo's point that a corporation is simply made up of those who are there.

We can get closer to our goal, however, if we consider what Innocent had to say about the agents of a corporation, particularly these collegia personalia. These groups of people naturally had common goals and interests, and it was important for the Decretalists to explain how these interests could be represented. ${ }^{46}$ One example Innocent dealt with was that of a cleric representing his prebend. Innocent thought it was only natural for a cleric to be able to use on behalf of his prebend because, according to the Digest, a beneficiary of a usufruct is a person who can sue. Moreover, a prebend itself can have its own iura et possessiones, just as a bishopric, abbey, hospital, house, dignity, or administration can. ${ }^{47}$ Naturally, a prebend requires some sort of agent for it to act, but it is equally clear that 'a certain personality is predicated' of it as well. ${ }^{4}$ In another comment to the same decretal, Innocent made the comparison between a prebendarius and a ususfructuarius even more explicit. ${ }^{49}$

In summary, then, a religious college or corporation, a collegium personale, exists in analogy to a personal servitude, and the agent of this college is analogous to one who holds a personal servitude (usufruct in this case). Servitudes are, moreover, rights of a sort, 'lesser real rights' according to one classification. ${ }^{50}$ There is thus a temptation to think that Innocent thought of a corporation, at least in the case of a collegium personale, as an entity that simply signifies a group of men brought and bound together by a common cause, and which is in a sense the summation of the rights and possessions that are vested in the individuals of the group, $5^{1}$ even if

that he was working with a legal notion. See Glos. ord. ad Dig. 7.8.1.1, s.v. 'etiam usus nudus'

46 See the discussion in Rodriguez 1962, 305-15.

47 Innocent IV, Commentaria ad X 2.19.3, n. 1 (fol. 248ra-b). The text is corrupt here. I read quomodo for quoniam and domus for dominus. Rodriguez 1962, 306, who used the 1570 Venice edition has quodmodo (a typo?) and domus.

48 Rodriguez 1962, 306.

49 Innocent IV, Commentaria ad X 2.19.3, n. 3 (fol. 248rb).

50 Miller 1998, 65 .

51 In Baldus' Margarita for Innocent's commentary, we read regarding the pope's commentary to $\mathrm{X} 5 \cdot 39.52(53)$ (n. 35 above), he added to the idea that a universitas 
they are distinct from the rights and possessions of any one individual of the group..$^{2}$ However, this group can be treated of as a person for the express purpose of thinking about the shared rights and interests that are vested in the group. It is a legal 'person,' and it can be represented, but it is not 'real.' If this was what John meant by 'imaginary,' then Innocent probably would have agreed with him. 53

\section{Procurators and Agents in Ordinem vestrum}

The preceding analysis also sheds some light on some of the elements of Ordinem vestrum that the Franciscans were not so keen on, namely Innocent's pronouncements regarding the Order's 'agent' (nuncius), his official and de facto relationship with the Order, and his general powers. ${ }^{4}$ As we have seen, Innocent saw no theoretical difficulties in having someone act on behalf of a corporation. Clearly, as both Quo elongati and Ordinem vestrum demonstrate, this was what the agent was meant to do. In each case, the agent may actually have been presented by the brothers, but he is not, de iure (we must assume), an agent of the brothers. The real difference here between the bulls (aside from the fact that Innocent allowed these agents to procure 'useful' things in addition to the needs of the Order) is that whereas before the agent could deposit the alms sicut dominus with a spiritual friend, Innocent said the agent could hold onto the alms himself sicut dominus, or hand them over to a 'spiritual friend' that the Order could nominate if they wished. Additionally, while Quo elongati implies that the spiritual friend determined the expediency of using the alms for their needs, Ordinem vestrum claims the brothers themselves determined what was expedient (or even just useful); they could even decide to have him transfer the alms to another person or location.

'non est aliud quam homines qui in eo sunt, scilicet cum addito iuris intellectu, et addita significatione quae ex uniuerso sumitur' (The Margarita is appended to Innocent's commentary but unpaginated; the reference here comes from the penultimate page.) Bartolus made a similar point; see Ullmann $1948,86-87$, and Miethke 1969, 506 n. 206.

52 Berman 1983, 216, 220.

53 It is important to note that Innocent devoted far more space here to the question of swearing de veritate dicenda and accurately and honestly representing the group than to the few lines about thinking of the college as one person.

54 Pásztor 1986, 110-11, has highlighted the differences in a very straightforward fashion. 
In light of what Innocent said in his Commentary about corporations, I think we must read Innocent to have been thinking of rights. It harmonizes well with what we have seen regarding his corporation 'theory' The agent acts on behalf of a college to represent faithfully the wishes of the college. In this case the agent is to secure what the college-the members of the college-deem necessary or useful. His subsequent bull, Quanto studiosis (1247), makes this all the more obvious. This bull reiterated the claim of papal ownership, but it also, noting that the Order had to have frequent recourse to the Apostolic See because of this arrangement, allowed the brothers to establish and remove men, as often as it seems advantageous, who have 'the power to seek, sell, exchange, alienate, manage, spend, buy, and convert' things for the friars' use (in usum). 55 There were additional clauses about need and expediency, but, overall, one is reminded of Innocent's point that a 'corporation is even properly said to establish a procurator for the corporation's own affairs[... ]. Similarly, a corporation establishes an agent for affairs that are not its own' 56

As far as I can tell, Innocent did not comment on ius or usus in a way that would be of interest to the polemicists involved in the poverty controversy (or the historians who study them). His commentary to the twelfth chapter of the title De verborum significatione (X 5.40.12), which begins, 'Ius dictum est a iure possidendo,' is blank. 57 However, this much seems clear. When it suited the discussion, Innocent was certainly not opposed to thinking about a corporation as a 'person' who could be represented before the law, even if we must always remember that a corporation is not something separate or above the people who comprise it. Yet if a college is to be considered on the analogy of a servitude, it seems that what the agent of the college represents is to be thought of in terms of right(s).

55 Quanto studiosis (BF 1:487-88, no. 235).

56 Innocent IV, Commentaria ad X 2.7.5 (fol. $211 \mathrm{rb}$ ).

57 For some interpretations of this decretal, see Tierney 1991, 457-66. 
THE MICHAELISTS ON 'ORDO HABEAT USUM'

\section{Bonagratia of Bergamo's Tractatus}

Now that Innocent's position is sufficiently clear, let us turn to the Michaelist account of the relationship that a 'use of right' must have with an 'Order' It is not immediately apparent whether Francis of Marchia and William of Ockham, perhaps even Michael of Cesena, realized it, but they were faced with a far greater quandary than they let on in their writings. The problem was that Bonagratia of Bergamo (d.1342), the Franciscan procuratorcommonly described as most skilled in canon and civil law, but no great theologian ${ }^{8}$ — had already said what John would later say in Quia quorundam regarding a usus iuris in his Tractatus de Christi et apostolorum paupertate. 59

The title summarizes the content fairly well. Written some months before the first version of $A d$ conditorem was published, ${ }^{60}$ the treatise was meant to answer the question of whether it was heretical to say that Christ and the apostles had nothing individually or in common. As he saw it, the question could be asking three very different things. 'To have something' might mean: (1) to obtain something by right of lordship (or quasi-lordship), or ownership, and in this case a thing may properly be said to be an individual's or a college's; (2) 'to have' could also be taken in a broad sense, such as someone who holds a thing de facto or 'for the simple use of fact,' where there is no claim to the right of lordship or ownership; or (3) someone is said to have a thing because he has administration of it. ${ }^{61}$ Bonagratia ended up rejecting the last two modes as candidates for the question, but the reason he gave for rejecting them is crucial to the subject of our inquiry. It could not be about these two modes, he reasoned, because even if 'detaining a thing de facto,' 'using things by use of simple

${ }^{8}$ Oliger 1929, 320. Coincidentally, much the same has often been said of John XXII; see Damiata 1978-1979, 1:305.

59 The text (=De paup.) is edited in Oliger $1929,323-335$ and $487-511$. On Bonagratia's theory in general, in addition to Wittneben 2003, see Mäkinen 2001, 174-90; Miethke 1969, 371-375, 379-83, 387-92; Tabarroni 1990, 40-48; Tarello 1964, 422-43; Tierney 1997a, 148-53.

6o Ad cond. ${ }^{1}$ was published 8 December 1322 . Oliger 1929,320 , has reasoned that Bonagratia's text was probably written in the previous summer.

61 De paup., 324-25. See Kriechbaum 1996, 27-28, Miethke 1969, 371-72. 
fact,' or 'administering or dispensing things or holding them by mode of custody or deposit' could belong to many as individuals, it nevertheless cannot belong to a college or corporation. Bonagratia's rationale reminds us of John's position. A corporation may obtain the place of a person in things which are of right, but in things which are of fact, or where the action (factum) of a definite person is required, a college does not obtain the place of a person. ${ }^{62}$ In the remainder of the tract, Bonagratia spoke about the 'college of apostles' in connection with having things in the first sense of habere res. ${ }^{63}$ Thus this is is the sense in which we should understand Christ's injunction against possessing gold, silver, or money: distributive et etiam collective. He forbade 'possession of this kind not only to each individual [apostle], but to the whole college of apostles, ${ }^{\prime 64}$ and although he said that a slave, a filiusfamilias, or a religious has only simple use of fact, ${ }^{65}$ it would seem that Bonagratia held, along with John XXII, that an Order, though maybe not merely 'imaginary,' could only have a use of right.

He did not leave it at that, however. First he located use of fact within the sphere of ius naturale. He even twisted a famous passage of Roman law to reading that 'nature taught all animals this use. 66 A use of fact of this sort is thus irrenounceable; in fact, everyone who is indispensably obliged to preserve his or her own life is also unable to renounce the things without which they could not live. ${ }^{67}$

The second step was to redefine the corporation that owned the goods the apostles used so that it included all of the faithful. In response to his own question regarding who held the lordship of the things the apostles used, he strung together a long list of legal citations, including one to Innocent, and then explained that, just as the things of the Church

\footnotetext{
62 Bonagratia, De paup., 325-26. See Brunner 2006, 231, and Wittneben 2003, 127.

63 E.g., De paup., 488-89, 493-94, 507.

64 Bonagratia, De paup., 495.

65 Bonagratia, De paup., $5 \mathrm{O} 2$.

66 Bonagratia, De paup., 503, citing D. 5 d.a.c. 1, D. 35 c. 7, D. 1 c. 7 , and twisting Inst. 1.2. pr., and Dig. 1.1.1.3. References to canon law are taken from Friedberg 18791881.

67 Bonagratia, De paup., 503. This was a standard view. Cf. OND 61.119-122, 140-145 (OP 2:561-62), 62.71-74 (OP 2:564-65), 65.197-200 (OP 2:577-78); for analysis throughout his oeuvre, see McGrade 2002, 177-96. Francis did not have as much to say about natural law in this treatise; see, however, Mariani 1993 n. 258, 153-54; and n. 681, 317. See also Lambertini 2006 a.
} 
are common to the corporation of all the faithful (commune universitatis omnium fidelium), so it was with the apostles' things. ${ }^{68}$ In this way, Bonagratia was able to provide an account of what we might call the 'natural use' of the apostles while relocating the ownership of these goods within the larger community. Unfortunately, the analogy was not as fitting for the Franciscan situation. The difference between the two groups was that phrase Ordo habeat usum: no one granted the college of apostles a use, whether of fact or of right. Bonagratia's Tractatus thus hinted the problem of corporate poverty, but only began to anwer it.

\section{Michael of Cesena's Appeals of 1328}

The significance of John's criticism of the idea of corporate poverty was not realized right away. ${ }^{69}$ In his Pisan appeals, however, Michael (with the collaboration of Bonagratia), responded to John's adoption of Bonagratia's argument. The so-called Shorter Appeal is least satisfactory in this matter. This may be due, in part, to the fact that the main purpose of the Shorter Appeal was to expose the nine errors John 'dogmatized' in the bulls $A d$ conditorem, Cum inter, and Quia quorundam; it constantly refers the reader to the longer version for the detailed argument. Be that as it may, the sixth error concerns Cum inter, which was John's short, but studied and emphatic, opinion on the poverty of Christ and the apostles. In this bull John determined that it was heretical to say that Christ and the apostles have did not have some things individually or in common; and that it was also heretical to maintain that Christ and the apostles had no right of using, or of selling, donating, or acquiring the things Scripture says they had. $7^{\circ}$ The problem as Michael saw it, then, had only to do with the specific problem of the apostolic college; doubtless, he thought the situation of the apostolic college applied to the Franciscan situation as

68 De paup., 505-06, citing Innocent, Commentaria ad X 2.12.4, n. 3 (fol. 222ra-b). See n. 86 , below.

69 In the Appellatio Michaelis in Avenione, e.g., there is no discussion of corporate poverty beyond the general claim that the Franciscans' vow to have nothing tam in speciali quam in communi had the approval of both Exiit qui seminat (VI 5.12.3) and Exivi de paradiso (Clem. 5.11.1) —not to mention John's own approval of these two bulls; see G\&F, pp. 186-87.

$7^{\circ}$ For the text, see Tarrant 1983, 255-57. See Duval-Arnould 1984, 406-420 and Duval-Arnould 1990. 
well, but as we know, the apostles were not granted use collective. ${ }^{11}$ With a reference to Dilectissimis (C. 12 q. 1 c. 2), a key text for both sides of the poverty controversy, Michael wrote that the passage in Acts 4:3235 (or 2:44-45) did not refer simply to the community or college of apostles. Acts had to refer to the 'general and universal community' of believers because if these so-called common goods were appropriated to the apostle's particular college (speciali collegio), then these goods could not be common to the whole multitude of believers, 'for what is of a part is not of the whole. ${ }^{2}$

Michael properly dealt with our problem in the Longer Appeal, which was published the on the same day as the Shorter Appeal in September 1328. The Longer Appeal, like its shorter counterpart, is structured according to the glaring errors the Michaelists had detected in Ad conditorem, Cum inter, and Quia quorundam. Unsurprisingly, corporate poverty is an issue in all three of them, though the focus is different in each case. The fifth error of Ad conditorem was that it questioned the value and actuality of Franciscan poverty by suggesting that it was, in short, enigmatic and mathematical, or verbal rather than real.73 Part of Michael's response was to compare the need for any religio to ensure that no private person have or possess anything of his own to the need for 'the whole religio of the Friars Minor' to have nothing of its own. ${ }^{74}$ This religion, Michael continued, 'so

$7^{1}$ In the discussion of this sixth error, much of the App. min. thus shared Bonagratia's concern to show that John had to mean a positive law-based right, which Michael claimed was a litigible right in the sense that one can sue in court in the case of an infringement of this right. See App. min., 443-44.

72 App. min., 445. Cf. App. min., 431-32.

73 John was fond of this argument: it can be found in both versions of the bull; see Ad cond. ${ }^{1}, 85-86$, and Ad cond. ${ }^{2}$ 251-254 (Tarrant 1983, 250-51). If we think of the range of activities Quanto studiosus allowed the friars (even if the majority was not keen to adopt the bull), John's statement makes much more sense.

74 App. mai., 272-73. We might note in passing that Michael would probably not have found Innocent's comments to this part of the decretal particularly palatable. According to Innocent, Commentaria ad X 3.35.6 (fol. 432vb-33rb), regarding the 'abdicatio proprietatis [...] annexa regulae monachali,' the 'Papa potest dispensare cum monacho, quod habeat proprium vel coniugem, cum possit ordinem et naturam, quam dedit ordini, et substantiam tollere' The pope, however, needs to do so ex causa. Innocent proves that this has to be the case with an amusing hypothetical situation: Imagine that all of Christianity were in danger unless a monk became king (say because no one else knew how to govern the realm); surely in that case, he reasoned, the pope can dispense with the vow of personal poverty. 
far as concerns the abdication of the ownership of all things, which it does in common, is thought of as one person, or performs the function of one person'75 Michael then draws an analogy between a monk and monastery and the Franciscan Order and the whole community of believers. Just as something given, granted, or offered to a monk passes into the lordship of the whole college (whatever the intention of the donor), and into the management of the abbot (even if the donor is thinking nothing about the college), so what is given to the college, or congregation, of the Friars Minor passes into the lordship of the Roman Church and management of the pope. $7^{6}$

So far Michael was attempting to show the corporate non-lordship of his Order. Part of his argument depended upon his adaptation of Bonaventure's account of the fourfold joint possession (communitas) of temporal goods, which flow from a fourfold ius. 77 Divine law is responsible for the second type of communitas, which accounts for the 'primitive community of the believers and the followers of the apostolic life in the Church. ${ }^{\prime}{ }^{8}$

The third communitas, based as it is on humanly instituted law, describes the general civil Order. But it can also describe corporations within civil society. Corporations of this sort, however, have nothing to do with evangelical society; in fact, those interested in evangelical perfection are obliged to renounce this sort of community. The reason for this is that, as it is often noted in Roman law, when a community-fellowship might be a better term in this context-is dissolved, the goods and monies of the community are divided amongst its members. In other words, he said, 'what is a college's is said to be the individuals'.79 Michael concluded, then, in a vein similar to the idea we saw above, namely that a corporation is nothing other than the men who are there: 80 'Therefore, an exclusive, personal right to the common things of the college is said to belong to any one person of that community or college. ${ }^{\prime 81}$

App. mai., 273, citing Dig. 46.1.22.

$7^{6}$ App. mai., 273. The similarity of this last statement to the De paup. needs no elaboration.

77 Michael adapted and expanded Bonaventure's quadruplex communitas in a very significant way; cf. App. mai., 335-40 and Bonaventure, Apologia pauperum 10.1316, ed. in Bonaventure 1882-1902, 5:309a-10a.

78 App. mai., 337-38.

79 App. mai., 339.

8 o See above, n. 37 .

81 App. mai., 339. 
The fourth type of communitas describes ecclesiastical society. Unlike Bonaventure, who used this fourth type to develop an explanation for why other mendicant orders or bishops, who have no personal only 'collegial' ownership, may still be considered perfect, ${ }^{82}$ Michael focused on when this type of communitas arose, which, he said, happened 'after the Church came to the Roman princes' Emperor Constantine was the first. ${ }^{8}$ The crucial difference between this community and the second one is that 'an action and exception is given for these same houses, estates, possessions, and goods which are held in common,' and 'for that reason, this sort of community is said to have quasi-proprietas and dominium utile' The rationale was that the type of control a church (or agent of the church) could exercise over these goods fell in between that found in the second and third types. ${ }^{84}$ This was not a new idea: many canonists maintained, for instance, that a prelate could not alienate the goods of his church without the consent of the canons. ${ }^{85}$ Michael in fact quoted Innocent IV and Hostiensis on this very point. In their respective apparatus to the Liber extra, they noted that it was Christ who had (full) lordship and possession of the things of the Church; they belong to the bishops, prelates, or chapters only as it concerns governance and administration. ${ }^{86}$

Michael utilized all these ideas in his argument against the Franciscan Order having a use of right. Michael's response took several prongs. The first was an appeal to Exiit qui seminat, which explained that the brothers could not acquire anything for themselves individually or for their Order even in common, and that the Roman Church received the ownership and lordship of the goods of which it was licit for the Order and brothers

82 See the analysis in Lambertini 1990, 92-97. Michael also used it for this argument (App. mai., 346), but it was also crucial for his defense of corporate poverty.

83 App. mai., 340; cf. App. mon., 745-46.

84 App. mai., 341. On the term dominium utile, see Brett 1997, 20-22 and Coleman 2005, 611-16. Quasi proprietas is a unique term; it is comparable to what we might call 'restricted ownership' in Ockham; see OND 2.389-432, 4.295-306 (OP 1:308-o9, 336), 77.407-438 (OP 2:533-34).

85 Innocent IV, of course, found that there were times when consent was unnecessary: Commentaria ad X 1.3.21, n. 4 (fol. 19ra-b). For the general trend among the canonists, see Tierney 1998, 108-17.

86 App. mai., 341, citing Innocent IV, Commentaria ad X 2.12.4, n. 3 (fol. 222ra-b), and Hostiensis, In Decretalium V libros commentaria (= Hostiensis 1963) ad X 2.12.3(4) (fol. 42va: pagination resets with each book of the Decretals). Cf. Bonagratia's Appeal against Ad cond. ${ }^{1}$, in G\&F 93; noted by Miethke 1969, 380. 
to have the use. ${ }^{87}$ Whether or not one finds this response convincing, it clearly does not answer the problem posed by John: it could simply be argued that Nicholas spoke ambiguously here, for an Order simply cannot have a use of fact, and licet habere could easily be taken to mean something more than using a thing without any right whatsoever.

Michael made two other arguments. One was to equate the Order of the brothers with the 'profession of the brothers' Thus, when Exiit said that the profession of the brothers abdicated the 'ownership of use and lordship of everything,' it is clearly apparent that a use that is of right (according to the sense in Inst. 2.2.2) does not belong (convenit) to the Order or profession. ${ }^{88}$ As is clear, this is not a full answer to the question regarding the concession of use to the Order.

For his second point, Michael appealed to the fiction theory. Exiit had set down that friars can acquire nothing for the Order, even in common; and since acquiring something for someone else is of right and consists of a right,' it must be that only what are of fact belong befit an Order. The reason is simple: the Franciscan Order, which performs the function of a person, like an estate, town, society, or court, has abdicated everything of right and retained only what is of fact. ${ }^{89}$

A little further on he repeated this point with further, if questionable, references to Roman law, $9^{\circ}$ before attacking the idea that an Order is an imaginary person. What is imaginary de iure, he argued, does not really exist, we only pretend it does. Imaginary things, such as chimeras, can have no use of right. But an Order, such as a college, a people, a city represents in truth a person and performs the function of a person in the understanding and determination of the law (interpretatione et statuto iuris). 'Hence, had not the Order of Friars Minor had not abdicated them, things which are of right would belong to it.. ${ }^{11}$ In the eyes of the law, the Order is a person; and what this means is that this 'person' can renounce

\footnotetext{
87 App. mai., 377; see also App. mai., 372 and App. mon., 677-78.

88 App. mai., 378. Inst. 2.2.2 deals with res incorporales, the sort of things 'quae in iure consistunt' Azo's glosses to this section consistently equate the ius of something to the thing itself; e.g., in the gloss to ius hereditatis, he wrote: 'Idest herediatarium ius, quoad est hereditas: et sic de unoquoque' See Caprioli et al. 2004, 95-97, here 96.

89 App. mai., 377, citing Dig. 46.1.22.

90 Inst. 3.17.1 (but cf. 3.17.3), and Dig. 41.1.34, which, as the editors note, 'Non videtur esse ad rem'

91 App. mai., 378-79.
} 
a use of right. On the other side, Michael also maintained, similar to Innocent, that an Order is little more than the people who comprise it. The phrase 'brothers in common' is equivalent to 'the Order'; thus 'what is left to the brothers in common is understood to be left to the Order.' 92 And as for proof that a corporation might act 'of fact,' Michael quoted from Dig. 41.2.2: 'But we use this law: that municipal citizens can possess and acquire ownership through possession; and it is acquired for them both through a slave and through a free person.'93 According to Michael, by using both possidere and usucapere, it was clear that both what is of fact and what is of law befit a corporation, which performs the function of a person. ${ }^{94}$ Michael therefore defended Franciscan poverty by an appeal to the fiction theory. Where he differed from John was that he rejected the notion that an Order was an 'imaginary' person. As a legal person it could act; in this case it could renounce a right of use.

Michael's appeals were published in the fall of 1328. He was the reprobate who provoked Quia vir reprobus, John's final pronouncement just over a year later. In this bull, the pope re-clarified his opinion regarding evangelical poverty for the last time. With respect to the problem of an Order having anything other that a use of right, John had little to add. Part of the emphasis this time around was in connecting the problem of an Order's supposed use of right with the idea that an act of using was something exclusive to an individual agent (and inherently incommunicable). 95 The other relevant passage in Quia vir made sure that everyone understood that the use of right that befits an Order is not an individual (proprium) right, but one common to the whole Order. ${ }^{6}$ I suspect that this renewed emphasis on the right being common to the whole Order was partly responsible for the slant of Francis of Marchia's and William of Ockham's responses to the problem.

92 App. mai., 378.

93 A municeps was a citizen of a municipium, or free town, in antiquity. Michael seems to be designating the corporate nature inherent in the plural municipes, for which he had some grounds: see, e.g., Summa Paucapaleae, ad C. 17 q. 4 c. 1o, in Schulte 1965, 91: 'Municipes sunt in eodem municipio nati ab officio dicti eo, quod publicis officiis mancipati sunt;' repeated almost verbatim by Rufinus, Summa Decretorum ad C. 17 q. 4 C. 10, in Singer 1963, 375. See further, Michaud-Quantin 1970, 119-21.

App. mai., 379.

Quia vir, 559. Cf. OND 6.20-26 (OP 1:355); Improbatio nn. 145-146, 108-o9.

Quia vir, 581; cf. OND 62.1-13 (OP 2:563); Improbatio nn. 716-719, 328-29. 
Francis of Marchia's Improbatio

Francis of Marchia's (c. 1285/90-1344) Improbatio contra 'Quia vir reprobus' was probably the first full-scale response to John's bull,97 although he was certainly familiar with the contents of Michael's longer and shorter appeals..$^{8}$ However, often enough Francis modified Michael's response. In this case, the alteration resulted in omitting the key element of Michael's refutation of John's position.

Unlike Michael, but foreshadowing Ockham's methodology, Francis undertook a sort of running commentary to Quia vir, though if he actually commented on the whole bull, the text that has come down to us is incomplete. 99 Francis' answer to the pope's challenge, as one might expect from a theologian, had little to say about corporations in the sense we have considered thus far. It is true, Francis said, that a 'logical community' is imaginary and represented: for it is a 'community of reason,' abstracted from its particulars. But this is hardly the case with a 'collective community,' which is a true community in reality and not merely one of reason. The example Francis provided is that of ten men pulling a ship together. The factual (de facto) pulling of a ship requires, say, ten men, not one. Only together can the act be done. ${ }^{100}$ Thus, if use of fact required a 'true person,' it should be understood that this use of fact requires a true person or a community made up of true people.

97 It was likely written in 1330; Lambertini 2001, esp. 304-05, has argued for the chronological primacy of the Improbatio. For a general overview of Francis' life and works, see Schabel 2008. It has long been noted that Francis' text was an important source for Ockham's OND (cf. Offler's apparatus fontium, and Miethke 1969, 468-70, $505-16,521-27)$, but Roberto Lambertini is the first to provide a series of detailed studies on the interrelationships between the Michaelist texts, many of which are listed in Lambertini 2006b, 141-63.

$9^{8}$ He appears as a signatory to the two appeals as well: App. mai., 423; App. min., 455; but not the App. mon.; see further Mariani 1993, 6. It is interesting that Francis of Marchia, William of Ockham, and Bonagratia of Bergamo (in that order) are the first three mentioned in both cases.

99 Mariani 1993, 28-29, has doubted the text's incompleteness, but not conclusively. Regardless, if we use Ockham's divisions of the text as a basis of comparison, then the first two 'sections' are missing along with the last several sections (from partway through 115 to 124 ). Some of the early quotations of Quia vir do not follow the order of the bull: almost as if Francis intended a more thematic approach, but gave it up rather quickly.

100 Improbatio n. 161, 114. 
After all, there are many human acts where one 'true' person does not suffice, and a plurality is required instead. In the example of the actual (de facto) dragging of the ship, that actual dragging had to be attributed to the group, not any one individual. ${ }^{101}$ Finally, in Francis' opinion, it is absurd to say that use of fact requires a true person any more than a right of using does. ${ }^{102}$ It was an argument that Ockham would expand upon.

This is not, however, to deny the reality of a corporation: if we are speaking of corporations in general, then, Francis argued, 'a specific community is related to a general community just like one specific person is related to one specific community ${ }^{\prime 103}$ Francis employed this idea as an example of how it was possible for the college of the apostles to renounce corporate ownership, ${ }^{104}$ even going so far as to argue that the "community of apostles [...] held the place of one specific person' as it concerns the abdication of ownership, ${ }^{105}$ or of usus iuris. ${ }^{106}$

Francis' argument was an interesting one, but also one that failed to respond to the argument as to whether the Order may be considered a juridical 'person,' which was, after all, the focus of John's claim. This is even more apparent where he responded to the pope's point that the use of right that befits an Order had to be a 'common' one. To be fair, one of Francis' primary goals in the Improbatio was to prove that whenever John said 'use of right' or 'right of using,' he had to mean a right that was litigiosum et contenciosum, that is, a ius agendi-which was, of course, precisely what the Franciscans did not want to have in any way. In order to keep this study within reasonable limits, we must avoid delving into this interesting topic; for now let it suffice to say Francis focused the first part of his response on showing that it is clear from John's constitution-seu destitutione sua - that he meant to speak about a 'right of taking action' in

101 Improbatio n. 162, 114. See Improbatio n. 154, 111 on the double meanings of usus iuris - as the actus utendi iuris and the ipsum ius utendi-, and simplex usus facti-as the simplex actus utendi and the simplex facultas utendi. He further subdivides ius utendi at nn. 759-763, 341-42.

102 Improbatio n. 156, 112.

103 Improbatio n. 743,335 .

104 See Improbatio nn. 50-52,70-72; n. 1164, 473-74. Ockham would do much the same; see, e.g., OND 4.252-265, 6.115-138 (OP 1:335, 357-58), 94.264-279 (OP 2:712-13).

105 Improbatio n. 283,163 .

106 Improbatio n. $733,332$. 
court. ${ }^{107}$ Thus, he reasoned, John had to mean a right of using 'exclusive (proprium) in some way, particularly or collegially,' for no one can start a legal suit on behalf of a right of using that is only common and in no way exclusive except where someone wishes to appropriate for himself the common right (ius commune). ${ }^{108}$

In summary, then, while Francis insisted that a corporation was a 'real' thing in contrast to a 'logical' entity, it was only as real as the people who comprised it. This is not what John was saying, who was concerned only with a corporation as a legal entity; nor does it seem to match up properly with Innocent's understanding, which, though he would agree with Francis on this point, also viewed a corporation as the locus of a set of rights, which inhered in it-even if that meant inhering, ultimately, in the members. The difference between the two positions had a lot to do with what direction one viewed the corporation from. Francis was concerned with the agency of the individuals looking out through the corporation: no single Franciscan would want to take up any collegial right, even to act on behalf of the college. John, on the other hand, was thinking from the perspective of one granting a thing, 'use' in this case, to the college; he was looking 'in,' through the corporation, to the people who comprised it. Thus, the use, conceded as a right of use, was conceded to the Order-that is, in common to the people who comprised it.

\section{William of Ockham's Opus nonaginta dierum}

William of Ockham (c. 1288-1347) probably wrote his improbatio of Quia vir in the first half of $1332 .{ }^{109}$ The tract, the Opus nonaginta dierum, has the dubious distinction of being the longest defence of Franciscan poverty ever written. In it William built upon the arguments Francis and Michael had already made, though, despite the claim to the contrary, ${ }^{110}$ he also injected some ideas of his own into the rapidly-dying debate.

\footnotetext{
107 Improbatio nn. $725-730,330-31$. The short reason is that, according to John, a (non-legal, regular) action cannot be just without a right of using; and a right of using, for the Michaelists, implies the opportunity for vindication in the courts if the right is impeded.

108 Improbatio n. 730, 331-32.

109 Miethke 1969, 83. Baudry 1950, 150-53, suggested a redacted version in 1333 . Cautious estimates use the range 1332-1334.

110 See his concluding remarks: OND 124.461-477 (OP 2:857-58).
} 
The Venerable Inceptor actually had a great deal to say about corporations and representation in his opera politica, more in fact than we can plausibly cover here; ${ }^{111}$ yet his early position, as it pertains to the question we have been considering, remains relatively un-studied.

Ockham laid the issue out quite clearly in his Epistola ad Fratres Minores (1334). According to the letter, errors abound in John's various bulls; of the 'great number' in Quia quorundam, Ockham saw fit to mention seven - and provide a little commentary on the wider implications of John's assertions. The problem was three related assertions: that the Order is a 'imaginary and represented person'; that things of fact cannot belong to an Order; and that things of right can befit an Order. ${ }^{112}$ These three errors, he wrote, 'are so ridiculous that they in no way need disproving (improbatione), but derision'113 Ockham would return to this point in other works as well, but it was usually little more than a summary of the three errors. ${ }^{114}$ Only the OND and the Contra Benedictum present a detailed refutation of the pope's position.

When he discussed these three errors in the context of the poverty controversy, he included a fourth, related, error: that the Franciscan Order had a right of use to the things it used. Ockham made it clear that he understood the Roman law meaning lurking in the term. As he said, every

111 Lagarde 1963, 43-44, provided a brief account of Ockham's use of 'corporate' terminology, but it is in dire need of revision. He wrote, for instance that Ockham used the word universitas 'assez rarement', but the term is used quite frequently in the Dialogus (= Dial.). It is usually employed in the sense of universitas fidelium or mortalium (e.g., 3.1 Dial. 2.1 , 2.2, 2.26, 2.30; 3.2 Dial. 1.2, 1.3 , 1.5, 1.7, 1.8, 1.11, $1.19,1.31 ; 3.2$ Dial. $2.5,2.6,3.6)$, at least once as a universitas viventium (3.2 Dial. 1.7), as well as in the sense of 'corporation' or 'community': e.g., 3.2 Dial. 3.10, 3.17. In this case, I have relied on the forthcoming critical edition of John Kilcullen et al., which is available in a preliminary version at http://www.britac.ac.uk/pubS/ dialogus/ockdial.html.

112 Epistola ad Fratres Minores (OP 3:9.29-10.3); at Octo quaestiones 8.7.49-55 (= OQ; OP 1:206) it is suggested that 'ad minus sunt circiter nonaginta' errors in his bulls.

113 OND 6.413-414 (OP 1:365). Cf. Miethke 1969, 507-08, who, in the following pages, attempted to relate this position to Ockham's philosophical views.

114 Contra Benedictum 1.8 (= CB; OP 3:189.26-191.39); Compendium errorum Ioannis Papae XXII 3.56-74 (OP 4:30-31); Tractatus contra Ioannem 24 (OP 3:102.27-103.12); De imperatorum et pontificum potestate 27.257-294 (OP 4:335-36); and OQ 8.7.112125 (OP 1:208). See 3.2 Dial. 1.29 for a different application of corporation theory. The online edition for this section is not yet reader-friendly at this point, but it seems to differ very little from Ockham 1962, fol. 246va. 
use of right is a usus nudus, or a usufruct. ${ }^{115}$ The Order, of course, does not have this kind of use, for Clement had forbidden the Order to litigate in Exivi de paradiso (Clem. 5.11.1), and a use of right was a use that one could defend in court. Thus, one could be sure the Order did not have a use of this sort. ${ }^{116}$

Ockham dealt with the other errors in turn. He also doubted in the strongest of terms that a communitas 'bears an imaginary or represented persona' Like Francis, he argued that this made no sense, not to mention contradict other dicta of the pope. Whatever can have a real act is not imaginary and represented, and the Church can exercise many real acts, such as judge between litigants, defend the Church's goods, and many other things. ${ }^{117}$ Similarly, John also insisted that the Order of Friars Minor has a right of using in the things they used, which would be impossible if the Order were an imaginary and represented person. Therefore, he concluded, the pope did not really think that the Order (or any other community) was really imaginary. ${ }^{118}$

Ockham addressed the issue of representation in his account of who owned the goods that the apostles used. There were three possibilities. In all cases the goods were common to the general community of believers, but in the second case Ockham suggested that there may be a common sort of lordship by which someone could litigate in the name of the whole community. In this case, the apostles would not have more than simple use of fact, either individually or in respect of their specific collegethough not because they lacked a right common to their college and to the others. ${ }^{119}$ Next, Ockham related Francis' argument regarding the pulling of a ship. Some acts, it is true, require a unique individual, but others clearly require the collective efforts of several people. ${ }^{120}$

A community, in short, is not one true person, but several true people; and an Order is not a 'unique' true person, but is true people (est verae

\footnotetext{
115 OND 62.200-203 (OP 2:568); on usus nudus cf. his comments at OND 2.132-154 (OP 1:301-02) with Inst. 2.5.1-5.

116 OND 62.200-201 (OP 2:568).

117 OND 6.424-429 (OP 1:365).

118 OND 6.433-438 (OP 1:366).

119 OND 106.84-90 (OP 2:772). A few lines further on, Ockham made an allusion that made it clear he was thinking in terms of the fourth type of communitas outlined by Michael and Bonaventure (see above, n. 77 , for references).

120 OND 6.440-446 (OP 1:366); cf. 62.279-280 (OP 2:570).
} 
personae), just as a people is not one man, but is many men. ${ }^{121}$ A people is many men gathered in unum, just like a community of the faithful is many faithful people professing one faith. 'A community is not some fantastic or imaginary thing, but is a true person'; and the same goes for a herd of swine, or a city, which is not singular (unica), but is several true things. ${ }^{122}$ Therefore, as Miethke noted, when Nicholas III said that the 'Order' had this use, this simply meant that the friars had this use, for the brothers are the Order. ${ }^{123}$ This argument was, in short, similar to-but more pointed than-Michael's claim in the App. mai.; it was, in fact, even closer in spirit both to the gloss 'Non debetur' and to comments Ockham had made in his academic writings. ${ }^{124}$

Elsewhere Ockham made an argument reminiscent of Francis' description of a logica communitas. If, he said, the Franciscan Order were only an imaginary and represented person, the same must be said of the Church. This would be absurd, however, because anything only represented and imaginary is a fantasy (fantasticum) and does not (fully) exist outside the mind in reality (in re). ${ }^{125}$ As to whether things of fact can befit an Order, if this were impossible, then one would have to conclude that they could not befit any community or college: neither the Church, nor a general council, nor the congregation of the faithful, nor a people, nor a crowd, nor a folk, nor a city, kingdom, nor any sort of corporation or community. Yet examples from Scripture and canon law bear out the opposite. ${ }^{126}$

121 OND 62.281-283 (OP 2:570). At OND 27.55-70, 88.331-335 (OP 1:478, 2:66162) and Breviloquium 3.15.45-66 (OP 4:191-92), Ockham made the point that the common lordship in a monastery is one that is common over time as well: if there is but one monk now, he still holds lordship in common with the past and future members of the monastery for it is preposterous to think that it turns into individual lordship while he is alone. As Miethke 1969, 514-15, has noted, this has implications for his corporation theory in general.

122 OND 6.446-455 (OP 1:366). Cf. 3.1 Dial. 2.1.

123 Miethke 1969, 510.

124 See n. 92 and n. 37 above. Miethke 1969, 511-13, noted the connection to Ockham's Sentence commentary and the Summula philosophiae naturalis.

125 OND 62.211-220 (OP 2:568); cf. 62.283-287 (OP 2:570).

126 OND 62.227-256 (OP 2:568-69); cf. 6.415-420 (OP 1:365). It should be noted that Innocent found nothing particularly significant in the two decretals (X 1.1.2 and 4.1.1) Ockham mentioned in this context; see his Commentaria to these passages (fol. 2rb, 463ra). CB 1.8 (OP 3:190.17-24) provides the longest list of scriptural references. 
The third error was that although things of fact could not, apparently, befit an Order, things of right could. According to Ockham, 'every right is ordered to some action'; that, in other words, what is of right can only befit what those things of fact can befit. And of course, nothing can befit something that is merely imaginary. ${ }^{127}$ In Contra Benedictum he expanded slightly on his argument:

To say, as [John] does, that an imaginary and represented person can have things of right and not a real action is so fantastically said that those accustomed to fantasies can in no way grasp this; for fantasists generally maintain that what exists only in the mind through a mental image cannot not have real rights. ${ }^{128}$

John's argument also fails, he explained, because if a real action is incompatible with something by its very nature, the same must be true for the right of exercising that real action. Although he has switched from the usus facti/usus iuris pair to actus realis/ius exercendi actum realem, so far the argument is pretty much the same. The crucial addition is that 'An Order can have rights and real actions'; from there he went on to list several 'real' acts, like the act of judging, correcting, dispensing the sacraments, managing ecclesiastical things. An Order is, after all, 'true and real persons' in the same way that the Church, or congregation of the faithful is true and real persons. ${ }^{129}$ Ockham wrote the Contra Benedictum some five or six years after the Opus nonaginta dierum (1337-38), ${ }^{130}$ which may explain why he is suddenly willing to stress the fact that an Order can-the verb posse is important here-have rights. It fits well with his general argument, to be sure, but this was very close to the point John had been making, namely, that an Order had to have rights, that that is all an Order can have. It is therefore somewhat surprising that Ockham would chose to stress this point, regardless of the context in which he wrote it.

\section{SOME CONCLUSIONS}

In conclusion, we should say that, of all the opinions we have considered on the nature of corporations, those expressed in the App. mai. seem to make the most sense in light of Innocent's own views. Innocent's opinion

\footnotetext{
127 OND 62.259-263 (OP 2:569); cf. 62.287-289 (OP 2:570). See Miethke 1969, 510.

128 CB 1.8 (OP 3:190.29-34).

129 CB 1.8 (OP 3:191.4-14).

130 Baudry 1950, 189 .
} 
seems ambiguous though. If one were to judge solely by his Commentary, one would be hard-pressed to find a reason for why he would agree to Michael's account of how a corporation may be granted anything other than rights - rights, which, in the end, devolved to the actual members of the corporation in common. The increased powers he granted to the nominated agents of the Order in Quanto studiosis would seem to bear this out as well. And although we have seen how Innocent did not discuss usus per se, his familiarity with Roman law makes it seem likely that he would understand a grant of usus to an Order to be one of right, not of fact. ${ }^{131}$

Concerning the 'represented' nature of an Order, Innocent, John, Bonagratia, and Michael seem to be in agreement to a certain extent; Francis and Ockham missed the point. But I suspect that they were more concerned with the philosophical tradition of repraesentatio and especially John's use of the term 'imaginary,' which John perhaps had little justification to employ. The Michaelists were usually keen to jump upon any chance to impugn John's bulls, and they clearly saw an opportunity here. From their arguments, we should assume that Francis, and Ockham following him at first, chose to interpret the pope to mean that an Order was only a represented and imaginary person. And in both cases they gave arguments to show that this could not be true. An Order was like the Church, made up of real people. But as we have seen, no one denied this. ${ }^{132}$ As J. P. Canning has shown, for Baldus (d.1400) a 'populus is at the same time both an abstract entity and real men,' that they are two aspects of the same thing, but he "never maintains that the populus as a conceptualization performs these legislative and governmental functions'133 Mutatis mutandis, the same, I think, could be said of Innocent or

${ }^{131}$ One of many other issues where further study may prove fruitful would be to examine more closely Innocent's writings regarding the need for a corporation to receive legitimate sanction (tacitum vel expressum) from a superior, particularly as a cornerstone of defenses of Franciscan poverty is that their Order and their brand of poverty possesses (repeated) papal approval. On Innocent's views, see Commentaria ad X 1.29(31).3 and 5.21.14, n. 2 (fol. 148ra, 526rb). See also the comments in Melloni 1986, 189-9o.

132 It thus may be true that Ockham's 'logical individualism' suited this position, but I doubt we need to chalk it up to being more than a standard view, or common-sense. Moreover, it is clear that Ockham did lend a sense of personality to the 'Church'-no less, that is, than Innocent did.

133 Canning 1980, 14 (emphasis Canning's). 
the Michaelists.

It would also seem that Michael's response was the most successful rebuttal of John's position in terms of answering what the pope was actually saying in an imprecise way. Michael utilized the distinction between the types of law-divine, natural, and positive-in a way that his confreres did not: he made explicit that the Order, considered as such, renounced positive law-based rights. Ockham was one step closer to this position in the Contra Benedictum, where he wrote that, despite what that fantasist, John, dreams up,' 'the Order of the Friars Minor is true people, who have and can have real rights and acts'134 What he forgot to mention, though, was that though it can have these kind of rights, it does not need to have them.

Jonathan Robinson $・$ University of Toronto

\section{REFERENCES}

Baudry, Léon (1950). Guillaume d'Occam. Sa vie, ses auvres, ses idées sociales et politiques. I. L'homme et les auvres. Paris: J. Vrin.

Berger, Adolf (1953). 'Encyclopedic Dictionary of Roman Law'. Transactions of the American Philosophical Society. NS. 43.2, 333-809.

Berman, Harold J. (1983). Law and Revolution. The Formation of the Western Legal Tradition. Cambridge, MA: Harvard University Press.

Bonaventure (1882-1902). Opera omnia edita studio et cura PP. Collegii a S. Bonaventura. 10 vols. Quaracchi: College of St Bonaventure.

Brett, Annabel S. (1997). Liberty, Right and Nature. Individual Rights in Later Scholastic Thought. Cambridge: Cambridge University Press.

Brooke, Rosalind B. (1959). Early Franciscan Government. Elias to Bonaventure. Cambridge: Cambridge University Press.

Brunner, Melanie (2006). 'Pope John XXII and the Franciscan Ideal of Absolute Poverty'. PhD thesis. University of Leeds.

Burns, J. H., ed. (2005). The Cambridge History of Medieval Political Thought, c. 350-c. 1450. Cambridge: Cambridge University Press.

134 CB 1.8 (OP 3.191.36-39), citing C. 24 q. 1 c. 20. 
Burr, David (2001). The Spiritual Franciscans. From Protest to Persecution in the Century After Saint Francis. Philadelphia: University of Pennsylvania Press.

Canning, Joseph P. (1980). 'The Corporation in the Political Thought of the Italian Jurists of the Thirteenth and Fourteenth Centuries'. History of Political Thought 1.1, 9-32.

- (2005). 'Government. II. Law, Sovereignty and Corporation Theory, 1300-1450'. In: The Cambridge History of Medieval Political Thought, c. 350-c. 1450 . Ed. by J. H. Burns. Cambridge: Cambridge University Press, $454-476$.

Caprioli, Severino et al., eds. (2004). Glosse preaccursiane alle Istituzioni: Strato azzoniano. Libro secondo. Fonti per la storia dell'italia medievale. Antiquitates 14. Rome: Istituto storico italiano per il medio evo.

Coleman, Janet (2005). 'Property and Poverty'. In: The Cambridge History of Medieval Political Thought, c. 350-c. 1450. Ed. by J. H. Burns. Cambridge: Cambridge University Press, 6o7-648.

Congar, Y. M.-J. (1958). 'Quod omnes tangit ab omnibus tractari et approbari debet'. Revue historique de droit français et étranger. 4e sér. 36, 210-259. repr. in Yves M.-J. Congar 1982, III.

Congar, Yves M.-J. (1982). Droit ancien et structures ecclésiales. London: Variorum.

Damiata, Marino (1978-1979). Guglielmo d'Ockham: Povertà e potere. 2 vols. Florence: Edizioni Studi Francescani.

Delorme, Ferdinand M. (1910). 'Diffinitiones capituli generalis O.F.M. Narbonensis (1260)'. Archivum franciscanum historicum 3, 491-504.

Duval-Arnould, Louis (1984). 'La Constitution "Cum inter nonnullos» de Jean XXII sur la pauvreté du Christ et des Apôtres: Rédaction préparatoire et rédaction définitive'. Archivum franciscanum historicum $77,406-420$.

- (1990). 'Élaboration d'un document pontifical: les travaux préparatoires à la constitution apostolique Cum inter nonnullos (12 novembre 1323)'. In: Aux origines de l'état moderne: le fonctionnement administratif de la papauté d'Avignon. Rome: École français de Rome, 385-409.

Elizondo, Fidelis (1962). 'Bullae «Quo elongati» Gregorii IX et «Ordinem vestrum » Innocentii IV. De duabus primis regulae Franciscanae authenticis declarationibus'. Laurentianum 3, 349-394.

Esser, Cajetan, ed. (1978). Opuscula sancti patris Francisci Assisiensis. Grottaferrata: College of St. Bonaventure. 
Fehi, Ioannis, ed. (1965). Corpus iuris ciuilis Iustinianei cum commentariis Accursii, scholiis Contii et D. Gothofredi lucubrationibus ad Accursium in quibus glossae obscuriores explicantur, similes E contrariae afferuntur, vitiosae notantur. Osnabrück: O. Zeller.

Flood, David (1996). 'Franciscan Poverty: A Brief Survey'. In: Nicolaus Minorita: Chronica. Documentation on Pope John XXII, Michael of Cesena and The Poverty of Christ with Summaries in English. A Source Book. Documentation on Pope John XXII, Michael of Cesena and The Poverty of Christ with Summaries in English. A Source Book. Ed. by Gedeon Gál and David Flood. St. Bonaventure, NY: The Franciscan Institute, 1-53.

Friedberg, Aemilius, ed. (1879-1881). Corpus iuris canonici. 2 vols. Editio lipsiensis secunda. Leipzig: Bernhardi Tauchnitz.

Gál, Gedeon and David Flood, eds. (1996). Nicolaus Minorita: Chronica. Documentation on Pope John XXII, Michael of Cesena and The Poverty of Christ with Summaries in English. A Source Book. St. Bonaventure, NY: The Franciscan Institute.

Gierke, Otto (1938). Political Theories of the Middle Age. Trans., with an introd., by F. W. Maitland. Cambridge: Cambridge University Press.

Grundmann, Herbert (1961). 'Die Bulle «Quo elongati » Papst Gregors IX'. Archivum franciscanum historicum 54, 3-25.

Heft, James (1986). John XXII and Papal Teaching Authority. Lewiston, NY: The Edwin Mellen Press.

Hostiensis (Henricus de Segusio) (1963). In Decretalium V libros commentaria. 2 vols. Turin: Bottega d'Erasmo.

Kilcullen, John et al., eds. (1995-). William of Ockham: Dialogus. The British Academy. URL: http: / /www.britac .ac.uk/pubS/dialogus / ockdial.html.

Kriechbaum, Maximiliane (1996). Actio, ius und dominium in den Rechtslehren des 13. und 14. Jahrhunderts. Ebelsbach: Aktiv Druck \& Verlag $\mathrm{GmbH}$.

Krueger, Paulus et al., eds. (1966). Corpus iuris civilis. 3 vols. Dublin: Weidmanns.

Lagarde, Georges de (1963). La naissance de l'ésprit lä̈que au déclin du moyen âge. Vol. 5: Guillaume d'Ockham: Critique des structures ecclésiales. Louvain: Éditiones Nauwelaerts.

Lambertini, Roberto (1990). Apologia e crescita dell'identità francescana (1255-1279). Nuovi studi storici 4. Rome: Istituto storico italiano per il medio evo. 
Lambertini, Roberto (200o). La povertà pensata. Evoluzione storica della definizione dell'identità da Bonaventura ad Ockham. Collana di storia medievale 1. Modena: Mucchi Editore.

- (2001). 'Francesco d'Ascoli e la polemica francescana contro Giovanni XXII: A proposito dei rapporti tra l'«Improbatio» e l' «Appellatio magna monacensis »'. In: Scritti in onore di Girolamo Arnaldi offerti dalla Scuola Nazionale di studi medioevali. Ed. by Andrea Degrandi et al. Rome: Istituto Storico italiano per il medio evo, 279-308.

- (2006a). 'Natural Law, Religious Poverty and Ecclesiology According to Francis of Marchia'. In: Intellect et imagination dans la philosophie médiévale / Intellect and Imagination in Medieval Philosophy / Intelecto e imginação na filosofia medieval. Actes du XI Congrès Internationale de philosophie médiévale de la Société Internationale pour l'Étude de la Philosophie Médiéval (S.I.E.P.M.) Ed. by M. C. Pacheco and J. F. Meirinhos. 3 vols. Turnhout: Brepols, 3:1625-1635.

- (2006b). 'Poverty and Power: Franciscans in Later Medieval Political Thought'. In: Moral Philosophy on the Threshold of Modernity. Ed. by J. Kraye and R. Saarinen. Dordrecht: Springer, 141-163.

Lambert, Malcolm D. (1998). Franciscan Poverty. The Doctrine of the Absolute Poverty of Christ and the Apostles in the Franciscan Order, 1210-1323. 2nd ed. St. Bonaventure, NY: The Franciscan Institute.

Mäkinen, Virpi (2001). Property Rights in the Late Medieval Discussion on Franciscan Poverty. Recherches de Théologie et Philosophie médiévales, Bibliotheca 3. Leuven: Peeters.

Mariani, Nazareno, ed. (1993). Francisci de Esculo, OFM, Improbatio contra libellum domini Iohannis qui incipit 'Quia vir reprobus'. Spicilegium bonaventurianum 28. Grottaferrata: Editiones collegii S. Bonaventurae ad Claras Aquas.

McGrade, Arthur Stephen (1980). 'Ockham and the Birth of Individual Rights'. In: Authority and Power. Studies on Medieval Law and Government Presented to Walter Ullmann on his Seventieth Birthday. Ed. by Brian Tierney and Peter Linehan. Cambridge: Cambridge University Press, 149-165.

- (2002). The Political Thought of William of Ockham. Personal and Institutional Principles. Cambridge: Cambridge University Press.

Melloni, Alberto (1986). 'William of Ockham's Critique of Innocent IV'. Franciscan Studies 46, 161-203. 
Michaud-Quantin, Pierre (1970). Universitas. Expressions du mouvement communautaire dans le moyen-âge. Paris: J. Vrin.

Miethke, Jürgen (1969). Ockhams Weg zur Sozialphilosophie. Berlin: Walter de Gruyter \& Co.

Miller, D. L. Carey (1998). 'Property'. In: A Companion to Justinian's Institutes. Ed. by Ernest Metzger. Ithaca: Cornell University Press, 4279 .

Moorman, John (1998). A History of the Franciscan Order from Its Origins to 1517 . Oxford: Clarendon Press.

Mueller, Joan (2006). The Privilege of Poverty. Clare of Assisi, Agnes of Prague, and the Struggle for a Franciscan Rule for Women. University Park, PA: The Pennsylvania State University Press.

Ockham, William (1962). Opera plurima. Vol. 1: Dialogus de imperio et pontificia potestate. Farnborough: Gregg Press Limited.

Offler, H. S. et al., eds. (1956-1997). Guillelmi de Ockham opera politica. 4 vols. Manchester/Oxford: Manchester University Press [voll. 1-3]; Oxford: Oxford University Press [vol. 4].

Oliger, Livarius (1929). 'Fr. Bonagratia de Bergamo et eius Tractatus de Christi et apostolorum paupertate'. Archivum franciscanum historicum 22, 292-335, 487-511.

Pásztor, Edith (1986). 'Francescanesimo e papato'. In: Francesco, il francescanesimo e la cultura della nuova Europa. Ed. by Ignazio Baldelli and Angiola Maria Romanini. Rome: Istituto della enciclopedia italiana, 103-118.

Pennington, Kenneth (2005). 'Law. I. Law, Legislative Authority, and Theories of Government, 1150-1300'. In: The Cambridge History of Medieval Political Thought, c. 350-c. 1450 . Ed. by J. H. Burns. Cambridge: Cambridge University Press, 424-453.

Post, Gaines (1946). 'A Romano-Canonical Maxim, "Quod omnes tangit" in Bracton'. Traditio 4, 197-252.

Quillet, Jeannine (1971). 'Universitas populi et représentation au XIV siècle'. In: Der Begriff der Repraesentio im Mittelalter. Stellvertretung, Symbol, Zeichen, Bild. Ed. by Albert Zimmermann. Miscellanea Mediaevalia 8. Berlin: Walter de Gruyter, 186-201.

Robinson, Jonathan (2009). 'William of Ockham on the Right to (Ab-)Use Goods'. Franciscan Studies 67, 347-374.

Robson, Michael (2006). The Franciscans in the Middle Ages. Woodbridge: The Boydell Press. 
Rodriguez, Manuel J. (1962). 'Innocent IV and the Element of Fiction in Juristic Personalities'. The Jurist 22.3, 287-318.

Sbaralea, J. H. and C. Eubel, eds. (1983). Bullarium franciscanum. 7 vols. Rome: Vatican.

Schabel, Christopher (2008). 'Francis of Marchia'. In: The Stanford Encyclopedia of Philosophy (Winter 2008 Edition). Stanford: The Metaphysics Research Lab, Center for the Study of Language and Information, and Stanford University. URL: http : / / plato. stanford.edu/archives / win2008/entries/francis-marchia/.

Schulte, Johann Friedrich von, ed. (1965). Paucapalea. Summa über das Decretum Gratiani. Aalen: Scientia Verlag.

Shogimen, Takashi (2007). Ockham and Political Discourse in the Late Middle Ages. Cambridge Studies in Medieval Life and Thought, Fourth Series 69. Cambridge: Cambridge University Press.

Singer, Heinrich, ed. (1963). Summa decretorum magistri Rufini. Paderborn: Scientia Verlag.

Tabarroni, Andrea (1990). Paupertas Christi et apostolorum: L'ideale francescano in discussione (1322-1324). Nuovi studi storici 5. Rome: Istituto storico italiano per il medio evo.

Tarello, Giovanni (1964). 'Profili giuridici della questione della povertà nel francescanesimo prima di Ockham'. In: Scritti in memoria di Antonio Falchi. Milan: Dott. A. Giuffrè - Editore, 338-448.

Tarrant, Jacqueline, ed. (1983). Extravagantes Iohannis XXII. Monumenta Iuris Canonici, Series B: Corpus Collectionum 6. Rome: Biblioteca apostolica vaticana.

Tierney, Brian (1988). 'Canon Law and Church Institutions in the Late Middle Ages'. In: Proceedings of the Seventh International Congress of Medieval Canon Law. Ed. by Peter Linehan. Vatican City: Biblioteca apostolica vaticana, 49-69. repr. in Tierney $1997 \mathrm{~b}$, VII.

- (1991). 'Ius dictum est a iure possidendo: Law and Rights in Decretales, 5.40.12'. In: The Church and Sovereignty, c. 590-1918. Ed. by Diana Wood. Studies in Church History 9. Oxford: Basil Blackwell Publisher Ltd, 457-466.

- (1997a). The Idea of Natural Rights. Emory University Studies in Law and Religion 5. Grand Rapids, MI: Scholars Press.

- (1997b). Rights, Laws, and Infallibility in Medieval Thought. Aldershot: Variorum. 
- (1998). Foundations of the Conciliar Theory. The Contribution of the Medieval Canonists from Gratian to the Great Schism. Studies in the History of Christian Thought 81. Enlarged New Edition. Leiden: Brill. Ullmann, Walter (1948). 'The Delictal Responsibility of Medieval Corporations'. The Law Quartery Review 64, 77-96. repr. in Ullmann 1988, XII.

- (1988). Law and Jurisdiction in the Middle Ages. London: Variorum.

Wittneben, Eva Luise (2003). Bonagratia von Bergamo. Franziskanerjurist und Wortführer seines Ordens im Streit mit Papst Johannes XXII. Studies in Medieval and Reformation Thought 9o. Leiden: Brill. 